\title{
Livestock grazing effects on forage quality of elk winter range
}

\author{
PATRICK E. CLARK, WILLIAM C. KRUEGER, LARRY D. BRYANT, AND DAVID R. THOMAS
}

Authors are range scientist, USDA Agricultural Research Service, 800 Park Blvd., Plaza IV, Suite 105, Boise, Ida. 83712; professor, Department of Rangeland Resources, Oregon State University, Corvallis, Ore. 97331; range ecologist, USDA Forest Service, Washington, D.C. 20250; and professor, Department of Statistics, Oregon State University, Corvallis, Ore. 97331. At the time of the research, Clark was graduate research assistant, Department of Rangeland Resources, Oregon State University, Corvallis, Ore. 97331 and Bryant was wildlife biologist, USDA Forest Service, Pacific Northwest Research Station, La Grande, Ore. 97850.

\begin{abstract}
Carefully-managed livestock grazing has been offered as a tool to improve the forage quality of graminoids on big game winter range. Formal testing of this theory has thus far been done using hand clippers rather than livestock grazing. We report winter standing reproductive culm, crude protein, in vitro dry matter digestibility, and standing crop responses of bluebunch wheatgrass (Agropyron spicatum [Pursh] Scribn. \& Smith), Idaho fescue (Festuca idahoensis Elmer), and elk sedge (Carex geyeri Boott) to late-spring domestic sheep grazing. The study was conducted in 1993 and 1994 on a big game winter range in the Blue Mountains of northeastern Oregon. Sheep grazing and exclusion treatments were applied to 20-ha plots at 3 sites on the study area. Targeted utilization for grazed plots was $50 \%$ graminoid standing crop removal during the boot stage of bluebunch wheatgrass. Grazing did not influence the number of standing reproductive culms per plant in bluebunch wheatgrass. Crude protein and in vitro dry matter digestibility of bluebunch wheatgrass in grazed plots increased by 1.0 and 4.3 percentage points, respectively, over ungrazed plots. Grazing reduced the standing crop of bluebunch wheatgrass by $116.9 \mathrm{~kg} \mathrm{ha}^{-1} \mathrm{DM}$. Standing Idaho fescue reproductive culms decreased by 0.7 culms plant $^{-1}$ under grazing. Crude protein of Idaho fescue in grazed plots was 1.3 percentage points greater than in ungrazed plots. Crude protein and in vitro dry matter digestibility responses of elk sedge were inconsistent between years and may be related to utilization or growth differences between years. The levels of forage quality improvement in bluebunch wheatgrass and Idaho fescue obtained in this study could benefit the nutritional status of wintering Rocky Mountain elk (Cervus elaphus nelsoni Bailey). More research is needed regarding the effects of grazing on the winter forage quality of elk sedge.
\end{abstract}

Key Words: Agropyron spicatum, bluebunch wheatgrass, Carex geyeri, Cervus elaphus, elk sedge, Festuca idahoensis, forage conditioning, Idaho fescue, nutrition, phenology, reproductive culms.

Research was funded by USDA Forest Service, Cooperative State Research Service, and USDA Agricultural Research Service. Authors wish to thank S. Hardegree, M. Seyfried, E. Starkey, M. Vavra, and 2 anonymous reviewers for their critical review and comments on drafts of this manuscript.

Manuscript accepted 28 March 1999
Two native perennial bunchgrasses, bluebunch wheatgrass (Agropyron spicatum [Pursh] Scribn. \& Smith) and Idaho fescue (Festuca idahoensis Elmer) dominate the grasslands of big game winter ranges in northeastern Oregon. Anderson and Scherzinger (1975) suggested spring livestock grazing of bluebunch wheatgrass and Idaho fescue may enhance the forage quality and palatability of these bunchgrasses for wintering elk. On a state wildlife management area in northeastern Oregon, where livestock grazing had initially been prohibited, Anderson and Scherzinger (1975) reported wintering elk numbers had increased from 320 to 1,191 head during a 10-year period when a rest-rotation cattle grazing management system was used to condition forages. Other researchers have also witnessed increased winter elk use following cattle grazing treatments on bluebunch wheatgrass and Idaho fescue (Jourdonnais 1985, Jourdonnais and Bedunah 1990, Frisina and Morin 1991).

Anderson and Scherzinger (1975) hypothesized grazing bluebunch wheatgrass and Idaho fescue in the late spring would delay the phenological development of grazed plants and cause them to cure at a younger, more nutritious phenological stage providing higher quality forage than ungrazed plants. Late-spring grazing should also reduce reproductive culm densities of bunchgrasses (Anderson and Scherzinger 1975), and enhance their palatability (Murray 1984, Ganskopp et al. 1992). Clipping treatments have been used to test this hypothesis for bluebunch wheatgrass (Pitt 1986, Bryant 1993, Westenskow-Wall et al. 1994, Clark et al. 1998) but there are no data on the winter forage quality responses of bluebunch wheatgrass and Idaho fescue to late-spring livestock grazing. Elk sedge (Carex geyeri Boott), another prevalent forage in the region, often contributes substantially to the winter diet of elk (Skovlin and Vavra 1979, Sheehy 1987). The effects of spring defoliation on the forage quality of elk sedge have not been studied.

Our objective was to test the forage conditioning hypothesis of Anderson and Scherzinger (1975) by measuring the reproductive culm response of bluebunch wheatgrass and Idaho fescue and the winter forage quality and quantity responses of bluebunch wheatgrass, Idaho fescue, and elk sedge grazed by domestic sheep in the late spring. 


\section{Materials and Methods}

\section{Study Area}

The 2,073 ha study area was located within the McCarty Spring Big Game Winter Range Management Area on the USDA-Forest Service McCarty Spring Sheep Allotment in the Blue Mountains of northeastern Oregon approximately $45 \mathrm{~km}$ southwest of La Grande. The area is typical of foothill rangelands occurring at the interface of the bunchgrass steppe vegetation of the Columbia Basin Geological Province and the forest vegetation of the Blue Mountain Geological Province (Franklin and Dryness 1973).

Several shallow, nearly-parallel drainages oriented in a northerly or northeasterly direction dissect the area forming a series of broad, gently sloping ridges. Elevation ranges from $1,170 \mathrm{~m}$ to $1,536 \mathrm{~m}$. Vegetation on the open ridges is a bunchgrass grassland dominated by bluebunch wheatgrass, Idaho fescue, Sandberg bluegrass (Poa sandbergii Vasey), and western yarrow (Achillea millefolium L.) (See Hall 1973: GB-49-11). Vegetation in the shallow drainages is a mixed-conifer forest of ponderosa pine (Pinus ponderosa Dougl.), Douglas-fir (Pseudotsuga menziesii [Mirbel] Franco.), and grand fir (Abies grandis [Douglas] Forbes) with a shrub layer of mallow ninebark (Physocarpus malvaceus [Greene] Kuntze), common snowberry (Symphoricarpos albus [L.] Blake), and oceanspray (Holodiscus discol or [Pursh] Maxim.) and a herbaceous layer of elk sedge and pinegrass (Calamagrostis rubescens Buckl.) (See Hall 1973: CD-S711). Vegetation in the ecotone between the ridgetop grasslands and forested drainages is a pine-bunchgrass savanna containing a ponderosa pine overstory and an understory of Idaho fescue, elk sedge, and bluebunch wheatgrass (see Hall 1973: CP-G1-12). Soils on the ridgetops and droughty exposures are shallow, extremely stony to very cobbly, loams and silt-loams of the Anatone-Bocker complex (Dysterhuis and High 1985, Bryant 1993). Soils on the mesic exposures are probably Klicker stony silt loam.

Mean annual temperature (1989-1995) at Starkey Experimental Forest and Range, less than $4 \mathrm{~km}$ from the study area, was $6.6^{\circ} \mathrm{C}$ (Unpubl. data, on file at USDA Forest Service, Forestry and Range Sciences Laboratory, La Grande, Oregon). Mean annual maximum (August) and minimum (December) temperatures (1989-1995) at Starkey Experimental Forest and Range were 25.4 and $-7.2^{\circ} \mathrm{C}$, respectively. Maximum, minimum, and

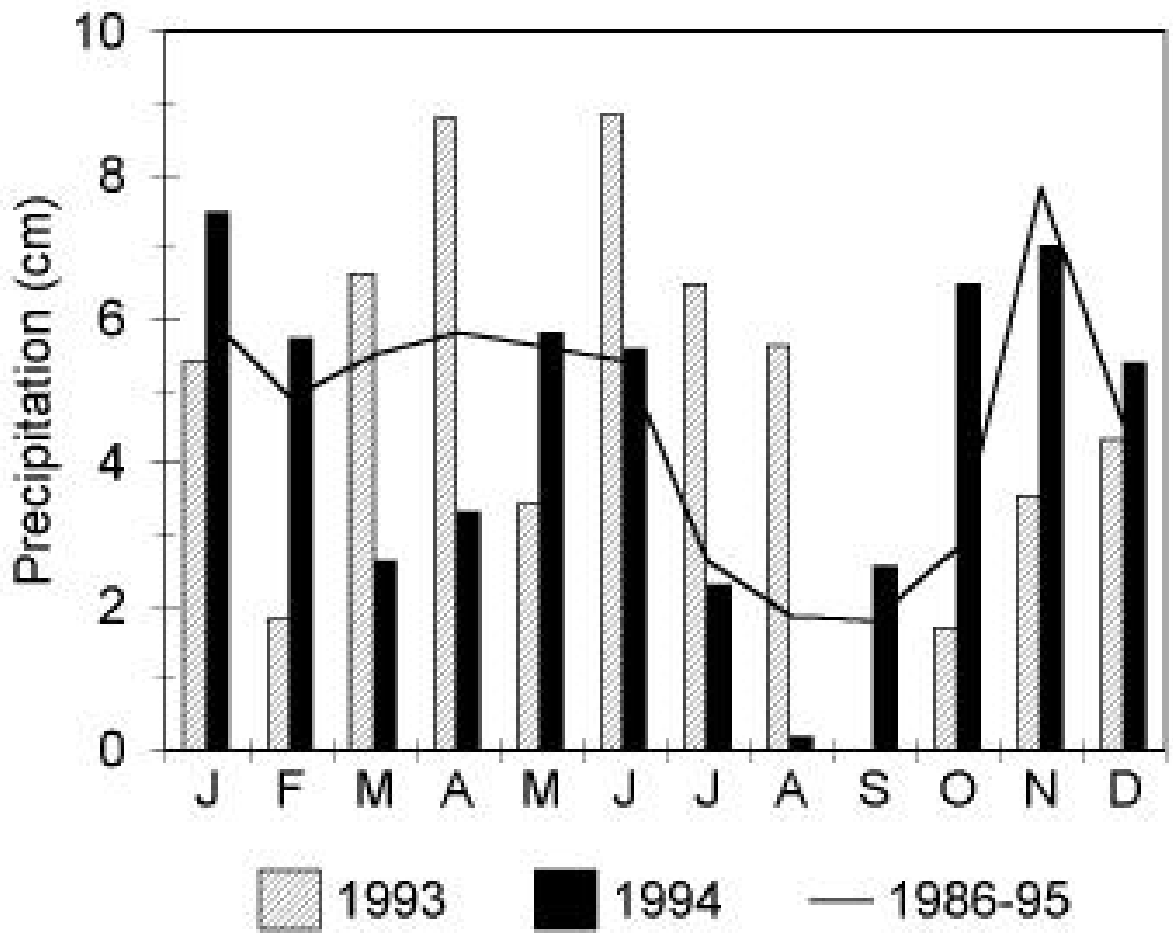

Fig. 1. Monthly precipitation at Starkey Experimental Forest and Range near La Grande, Ore. for 1993, 1994, and a 10-year average (1986 to 1995).

mean annual precipitation (1986 to 1995) at Starkey Experimental Forest and Range were $72.0,36.2$, and $54.8 \mathrm{~cm}$, respectively. Approximately $60 \%$ of the annual precipitation occurred between 1 December and 31 May as winter snow and spring rain. The amount and timing of late summer and fall rain is unpredictable, but it can promote additional growth in perennial grasses. Annual precipitation totals for 1993 and 1994 at Starkey Experimental Forest and Range were $56.6 \mathrm{~cm}$ and 54.4 $\mathrm{cm}$, respectively (Fig. 1).

Light to moderate levels of sheep grazing has occurred on the study area from early June until early October since 1950. Prior to 1950 the area had received moderate to heavy cattle grazing. Typically, 300 to 400 elk winter on or near the study area (Unpub. data, on file at Oregon Department of Fish and Wildlife, Northeast Region, La Grande, Ore.).

\section{Experimental Design}

A split plot experimental design was used. Three blocks containing 2 main plots each were established along selected ridges and associated drainages within the study area. These 3 blocks represented 3 different locations within the study area; Tybow Canyon, McCarty Spring, and Cabbage Spring. Each main plot was 250 $\mathrm{m}$ by $800 \mathrm{~m}$ and oriented with its long axis parallel to the drainage. Elevation and aspect of main plot pairs were similar. Three plant communities, occupying roughly equal areas, occured in each main plot:

1) Bunchgrass grassland dominated by bluebunch wheatgrass, Idaho fescue, and Sandberg bluegrass (ridgetops and large openings on droughty exposures).

2) Pine-bunchgrass savanna consisting of a ponderosa pine overstory and an Idaho fescue/elk sedge/bluebunch wheatgrass understory (mid-slope grassland-forest ecotone).

3) Mixed-conifer forest with a ponderosa pine/Douglas-fir/grand fir overstory, a ninebark/common snowberry/oceanspray shrub layer, and an elk sedge/pinegrass herbaceous layer (drainage bottoms and lower slopes).

Plant communities were treated as subplots within each main plot. The savanna and forest comminities were further divided into areas with tree canopy (i.e., areas under trees greater than $25 \mathrm{~cm}$ d.b.h.) and areas without tree canopy (i.e., open areas or areas under trees of $25 \mathrm{~cm} \mathrm{d.b.h.} \mathrm{or}$ less).

\section{Treatment Applications}

Main plots within each block were randomly assigned to 1 of 2 treatments: (1) sheep grazing during the boot stage of 
bluebunch wheatgrass, or (2) exclusion of sheep grazing. Sheep grazing, at a stocking rate of 52 ewe-lamb pairs ha ${ }^{-1}$, was applied for either a maximum of 3 days main plot $^{-1}$ or until approximately $50 \%$ utilization was reached on at least 1 of the 3 targeted forages. Electric fences kept sheep in the plots during treatment application and excluded them after treatment. Big game had open access to the plots. To simulate a rest-rotation grazing system, treatments within each block was reversed during the second year (1994).

In the first year of grazing, sheep accidently entered our exclusion main plot in Block 2 (McCarty Spring). The resulting forage use precluded its service as a control, consequently, Block 2 was dropped from the study.

Logistical problems prevented us from using sheep familiar with the study area in 1993. The ewe-lamb band used in 1993 was too agitated to graze effectively in the plots, and prevented us from reaching 50\% utilization on any of the targeted forages within the 3-day limit. The ewe-lamb band used in 1994 was familiar with the study area, actively foraged in the plots, and our 50\% utilization level was easily accomplished.

During late spring 1993, slight utilization of bluebunch wheatgrass ( 0.9 to $1.6 \%)$, Idaho fescue $(0.1$ to $0.9 \%)$, and elk sedge (1.8 to $3.1 \%$ ) by elk occurred in the grazing exclusion main plots of Block 1 and Block 3. We assumed this slight utilization would not confound the statistical analyses of treatment effects.

\section{Sampling Protocol}

Forage utilization and the number of standing reproductive culms per plant were assessed after treatment. Five, 150-m pace transects were randomly located in each plant community of each plot. Six sampling points were located at $25 \mathrm{~m}$ intervals along each transect. A $0.5-\mathrm{m}^{2}$ circular frame was positioned at each point, and forage utilization was estimated using an ocular estimate method (Pechanec and Pickford 1937). Within the same frame, the number of standing reproductive culms per species were counted and the total for each species was divided by the respective number of plants found in the frame. In the grassland community, 30 frames were sampled for utilization and number of reproductive culms in bluebunch wheatgrass and Idaho fescue. In the savanna, utilization of bluebunch wheatgrass, Idaho fescue, and elk sedge, and number of reproductive culms in bluebunch wheatgrass and Idaho fescue were estimated in 60 frames, with 30 frames under tree canopy and 30 frames in openings. In the forest community, 30 frames under tree canopy and 30 frames in openings were read for utilization of elk sedge. Transect means were treated as subsamples. Plot means for each species/community/canopy combination were treated as samples.

In early November, the number of reproductive culms per plant for bluebunch wheatgrass and Idaho fescue in the grassland and savanna types were resampled along 5 new transects per type. Forage samples were collected at 2 randomly selected points along transects in all 3 types. All the bluebunch wheatgrass, Idaho fescue or elk sedge within the 0.5$\mathrm{m}^{2}$ frame were clipped to a $2.5 \mathrm{~cm}$ stubble height and sorted by species. Forage samples were also collected in early March of both years along new transects.

Forages were oven dried at $50^{\circ} \mathrm{C}$, ground to pass a $1-\mathrm{mm}$ screen, and stored in airtight bags. Samples were analyzed for percentage crude protein (CP) (AOAC 1980), percentage in vitro dry matter digestibility (IVDMD) (Tilley and Terry 1963), and kg $\mathrm{ha}^{-1}$ of dry matter standing crop.

\section{Statistical Analysis}

Tests for treatment, period, canopy, sequence, and year effects on number of reproductive culms per plant, CP, IVDMD, and standing crop were conducted with General Linear Model (GLM) procedures (SAS 1988). Because treatments were reversed in 1994, a cross-over analysis was used to examine sequence effect. The sequence variable describes the order of treatment application. Sequence 1 represents plots ungrazed in 1993 and grazed in 1994 and Sequence 2 represents plots grazed in 1993 and ungrazed in 1994. Treatment, canopy, period, and sequence were analyzed as fixed effects, and year was analyzed as a random effect. Interactions between fixed effects and between fixed effects and year were analyzed and tested. Separate reduced models were developed for each species/plant community combination by systematically dropping non-significant, fixed-random effect interactions from the full models. Where significant effects were detected, Fisher's Least Significant Difference (LSD) procedure was used for mean separations (SAS 1988). All differences reported are significant at $\mathrm{P}<0.05$ unless stated otherwise.

\section{Results}

\section{Bluebunch Wheatgrass-Grassland Community}

Utilization of bluebunch wheatgrass in the grassland community was affected by treatment, sequence, and year (Table 1). Grazed plots received 38.9\% utilization while ungrazed plots received $0.8 \%$ utilization. Utilization under Sequence 1 (i.e., ungrazed in 1993 and grazed in 1994) $(\bar{X}=28.8 \%)$ was greater than under Sequence 2 (i.e., grazed in 1993 and ungrazed in 1994) $(\bar{x}=10.9)$, and utilization was higher in $1994(\bar{x}=28.0 \%)$ than in $1993(\bar{x}=11.7 \%)$.

Number of standing reproductive culms per bluebunch wheatgrass plant was not

Table 1. Main effects and interactions, with their respective p-values, for response variables of bluebunch wheatgrass occurring in bunchgrass grasslands on the McCarty Spring Big Game Winter Range Management Area in northeastern Oregon during 1993 and 1994.

\begin{tabular}{|c|c|c|c|c|c|c|}
\hline $\begin{array}{l}\text { Main Effects } \\
\text { and Interactions }\end{array}$ & $\begin{array}{c}\text { Degrees of } \\
\text { Freedom }\end{array}$ & $\begin{array}{c}\text { Forage } \\
\text { Utilization }\end{array}$ & $\begin{array}{c}\text { Number of } \\
\text { Reproductive } \\
\text { Culms per Plant }\end{array}$ & Crude Protein & $\begin{array}{c}\text { In Vitro } \\
\text { Dry Matter } \\
\text { Digestibility }\end{array}$ & $\begin{array}{l}\text { Standing } \\
\text { Crop }\end{array}$ \\
\hline & & \multicolumn{5}{|c|}{ 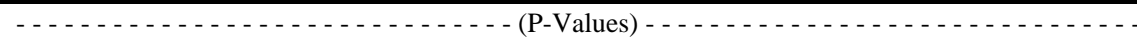 } \\
\hline $\mathrm{T}^{1}$ & 1 & $0.0094^{2}$ & 0.1641 & 0.0097 & 0.0021 & 0.0099 \\
\hline $\mathrm{P}$ & 1 & NA & 0.0438 & 0.0714 & 0.1381 & 0.7727 \\
\hline $\mathrm{T}^{*} \mathrm{P}$ & 1 & NA & 0.2535 & 0.8592 & 0.9691 & 0.5840 \\
\hline $\mathrm{S}$ & 1 & 0.0407 & 0.4942 & 0.3059 & 0.0426 & 0.0755 \\
\hline $\mathrm{S}^{*} \mathrm{P}$ & 1 & NA & 0.8379 & 0.3508 & 0.2593 & 0.9325 \\
\hline $\mathrm{Y}$ & 1 & 0.0485 & 0.0184 & 0.0018 & 0.0008 & 0.8332 \\
\hline
\end{tabular}

$\mathrm{T} \mathrm{T}=$ Treatment (grazed or ungrazed), $\mathrm{P}=$ Sampling period (June or November for reproductive culms and November or March for forage quality and quantity variables), $\mathrm{S}=$ Sequence or order of treatment application on a plot (ungrazed/grazed or grazed/ungrazed), and Y = Year (1993 or 1994).

${ }^{2} \mathrm{P}$-values $<0.05$ are printed in bold face. 
Table 2. Main effects and interactions, with their respective p-values, for response variables of bluebunch wheatgrass occurring in grazed and ungrazed pine-bunchgrass savannas on the McCarty Spring Big Game Winter Range Management Area in northeastern Oregon during 1993 and 1994.

\begin{tabular}{|c|c|c|c|c|c|c|}
\hline $\begin{array}{l}\text { Main Effects } \\
\text { and Interactions }\end{array}$ & $\begin{array}{c}\text { Degrees of } \\
\text { Freedom }\end{array}$ & $\begin{array}{c}\text { Forage } \\
\text { Utilization }\end{array}$ & $\begin{array}{c}\text { Number of } \\
\text { Reproductive } \\
\text { Culms per Plant }\end{array}$ & Crude Protein & $\begin{array}{c}\text { In Vitro } \\
\text { Dry Matter } \\
\text { Digestibility }\end{array}$ & $\begin{array}{l}\text { Standing } \\
\text { Crop }\end{array}$ \\
\hline $\mathrm{T}^{1}$ & 1 & $0_{0.001}^{2}$ & 0.1271 & $\begin{array}{c}\text { (P-Values) - } \\
\mathbf{0 . 0 0 0 1}\end{array}$ & 0.0036 & 0.4414 \\
\hline $\mathrm{P}$ & 1 & NA & 0.0862 & 0.0118 & 0.1378 & 0.5957 \\
\hline $\mathrm{C}$ & 1 & 0.0559 & 0.0235 & 0.0816 & 0.4666 & 0.0002 \\
\hline $\mathrm{T} * \mathrm{P}$ & 1 & NA & 0.7351 & 0.9855 & 0.2273 & 0.4848 \\
\hline $\mathrm{T}^{*} \mathrm{C}$ & 1 & 0.0453 & 0.9121 & 0.2484 & 0.9838 & 0.5035 \\
\hline $\mathrm{S}$ & 1 & 0.0001 & 0.8274 & 0.3571 & 0.7519 & 0.7217 \\
\hline $\mathrm{S} * \mathrm{P}$ & 1 & NA & 0.4699 & 0.8516 & 0.2457 & 0.6264 \\
\hline $\mathrm{S}^{*} \mathrm{C}$ & 1 & 0.3303 & 0.7297 & 0.0809 & 0.4646 & 0.8967 \\
\hline $\mathrm{S} * \mathrm{P} * \mathrm{C}$ & 1 & NA & 0.5110 & 0.7133 & 0.2397 & 0.8896 \\
\hline $\mathrm{Y}$ & 1 & 0.0001 & 0.0127 & 0.0019 & 0.0944 & 0.0053 \\
\hline
\end{tabular}

${ }_{\mathrm{T}}^{\mathrm{T}}=$ Treatment (grazed or ungrazed), $\mathrm{P}=$ Sampling period (June or November for reproductive culms and November or March for forage quality and quantity variables), $\mathrm{C}=$ Canopy (present or absent), $\mathrm{S}=$ Sequence or order of treatment application on a plot (ungrazed/grazed or grazed/ungrazed), and Y = Year (1993 or 1994).

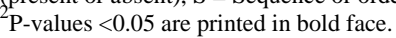

affected by grazing, however, significant sampling period and year effects were detected (Table 1). More reproductive culms were present in June $(\overline{\mathrm{x}}=3.7)$ than in November $(\bar{x}=1.9)$, and more reproductive culms occured in $1993(\bar{x}=3.9)$ than in $1994(\bar{x}=1.6)$.

Crude protein of bluebunch wheatgrass was affected by treatment and year (Table 1). Crude protein was higher in grazed $(\bar{x}=4.2 \%)$ than in ungrazed plots $(\bar{x}=3.2 \%)$. Crude protein was also higher in $1994(\bar{x}=4.4 \%)$ than in $1993(\bar{x}=3.0 \%)$.

Significant treatment, sequence, and year effects were detected for IVDMD of bluebunch wheatgrass (Table 1). In vitro grazed $(\bar{x}=42.2 \%)$ than in ungrazed plots $(\bar{x}=37.9 \%)$. In vitro dry matter digestibility was higher under Sequence 1 $(\bar{x}=41.2 \%)$ than under Sequence 2 $(\bar{x}=38.9 \%)$, and IVDMD was greater in $1994(\bar{x}=42.6 \%)$ than in $1993(\bar{x}=37.5 \%)$.

Standing crop of bluebunch wheatgrass in the grassland community was affected by treatment (Table 1). Grazing reduced the standing crop $\left(\bar{x}=135.0 \mathrm{~kg} \mathrm{ha}^{-1} \mathrm{DM}\right)$ dry matter digestibility was greater in

relative to grazing exclusion $(\overline{\mathrm{x}}=251.9 \mathrm{~kg}$ $\left.\mathrm{ha}^{-1} \mathrm{DM}\right)$.

\section{Bluebunch Wheatgrasss-Savanna Community}

Significant treatment, sequence, year, and treatment by canopy effects were detected for utilization of bluebunch wheatgrass in the savanna community (Table 2 and 3). Canopy and year affected the number of reproductive culms per plant (Table 2). More reproductive culms were present in the openings $(\bar{x}=1.3)$ than under the tree canopy $(\overline{\mathrm{x}}=0.5)$, and more culms occured in $1993(\bar{x}=1.4)$ than in $1994(\bar{x}=0.5)$.

Treatment, period, and year effects were detected for CP of bluebunch wheatgrass (Table 2). Grazing increased CP $(\overline{\mathrm{x}}=4.2 \%)$ relative to grazing exclusion $(\bar{x}=3.3 \%)$. Crude protein increased between the November $(\bar{x}=3.5 \%)$ and March sampling periods $(\bar{x}=4.0 \%)$, and CP was higher in $1994(\bar{x}=4.0 \%)$ than in $1993(\bar{x}=3.4 \%)$. Treatment and the interaction of period by canopy affected IVDMD of bluebunch wheatgrass (Tables 2 and 4).

Table 3. Mean levels of utilization (percent plant weight) on bluebunch wheatgrass as affected by treatment, sequence, year, and the interaction of treatment and canopy presence in pine-bunchgrass savannas on the McCarty Spring Big Game Winter Range Management Area in northeastern Oregon during 1993 and 1994.

\begin{tabular}{|c|c|c|c|c|c|c|c|}
\hline & \multirow[b]{3}{*}{ Treatment } & \multicolumn{2}{|c|}{ Sequence } & \multirow{2}{*}{\multicolumn{2}{|c|}{ Year }} & \multirow{2}{*}{\multicolumn{2}{|c|}{ Canopy }} \\
\hline & & \multirow{2}{*}{$\begin{array}{l}\text { Ungrazed- } \\
\text { Grazed }\end{array}$} & \multirow{2}{*}{$\begin{array}{c}\text { Grazed- } \\
\text { Ungrazed }\end{array}$} & & & & \\
\hline & & & & 1993 & 1994 & Absent & Present \\
\hline & $--\frac{--}{0.6 \mathrm{a}^{1}}$ & --- & $\begin{array}{c}---- \\
1.1\end{array}$ & $\begin{array}{c}(\%)--- \\
1.1\end{array}$ & --- & $\begin{array}{r}--- \\
0.4 \mathrm{a}\end{array}$ & $-\overline{0.7 \mathrm{a}}$ \\
\hline Grazed & $26.8 \mathrm{~b}$ & 6.6 & 46.9 & 6.6 & 46.9 & $31.2 \mathrm{~b}$ & $22.3 \mathrm{c}$ \\
\hline Mean & 13.7 & $3.3 \mathrm{a}$ & $24.0 \mathrm{~b}$ & $3.9 \mathrm{a}$ & $23.4 \mathrm{~b}$ & 17.8 & 11.5 \\
\hline
\end{tabular}

${ }^{\mathrm{M}}$ Means for main effects or treatment by canopy interactions which share a common letter are not significantly different $(\mathrm{P}>0.05)$.
Canopy and year affected the standing crop of bluebunch wheatgrass (Table 2). More standing crop was present in the openings ( $\bar{x}=109.5 \mathrm{~kg}$ ha DM) than under the tree canopy $\left(\bar{x}=38.1 \mathrm{~kg} \mathrm{ha}^{-1} \mathrm{DM}\right)$. Standing crop was greater in $1993(\overline{\mathrm{x}}=98.1$ $\left.\mathrm{kg} \mathrm{ha}^{-1} \mathrm{DM}\right)$ than in $1994\left(\overline{\mathrm{x}}=49.5 \mathrm{~kg} \mathrm{ha}^{-1}\right.$ DM).

\section{Idaho Fescue-Grassland Community}

Utilization of Idaho fescue by sheep in the grassland community was influenced by treatment, sequence, and year effects (Table 5). Idaho fescue in grazed plots received $31.5 \%$ utilization while $0.1 \%$ utilization occurred in ungrazed plots. Utilization was heavier under Sequence 1 $(\bar{x}=26.3 \%)$ than under Sequence 2 $(\bar{x}=5.2 \%)$, and utilization was greater in $1994(\bar{x}=26.2 \%)$ than in $1993(\bar{x}=5.3 \%)$.

Number of reproductive culms per Idaho fescue plant was not affected by grazing, however, a year effect was detected (Table 5). Number of reproductive culms per plant was higher in 1993 $(\bar{x}=4.0)$ than in $1994(\bar{x}=1.0)$

Significant treatment, sequence, and year effects were detected for CP of Idaho fescue (Table 5). Idaho fescue in grazed plots was higher in $\mathrm{CP}(\overline{\mathrm{x}}=6.2 \%)$ than in ungrazed plots $(\bar{x}=4.9 \%)$. Crude protein was greater under Sequence $1(\bar{x}=5.9 \%)$ than under Sequence $2(\bar{x}=5.2 \%)$, and CP was higher in $1994(\bar{x}=6.5 \%)$ than in 1993 $(\bar{x}=4.6 \%)$.

In vitro dry matter digestibility of Idaho fescue was not affected by grazing but a period effect was detected (Table 5). In vitro dry matter digestibility declined between November ( $\mathrm{x}=47.1 \%)$ and March $(\bar{x}=42.5 \%)$. The standing crop of Idaho 
Table 4. Mean levels of in vitro dry matter digestibility for bluebunch wheatgrass as affected by grazing treatment and the interaction of sampling period and canopy presence in pine-bunchgrass savannas on the McCarty Spring Big Game Winter Range Management Area in northeastern Oregon during 1993 and 1994.

\begin{tabular}{|c|c|c|c|c|c|}
\hline & \multirow[b]{2}{*}{ Period } & \multicolumn{2}{|c|}{ Treatment } & \multicolumn{2}{|c|}{ Canopy } \\
\hline & & Ungrazed & Grazed & Absent & Present \\
\hline \multicolumn{6}{|c|}{$---------------(\%)---------------$} \\
\hline Early & 40.0 & 38.1 & 41.8 & $40.7 \mathrm{a}$ & $39.3 b$ \\
\hline Late & 38.8 & 38.0 & 39.6 & $37.5 \mathrm{c}$ & $40.0 \mathrm{a}$ \\
\hline Mean & 39.4 & $38.1 \mathrm{a}^{1}$ & $40.7 \mathrm{~b}$ & 39.1 & 39.7 \\
\hline
\end{tabular}

${ }^{\mathrm{T}}$ Means for main effects or period by canopy interactions which share a common letter are not significantly different $(\mathrm{P}>0.05)$.

fescue in the grassland community was not affected by any of the variables measured (Table 5).

\section{Idaho Fescue-Savanna Community}

Treatment, sequence, and year also affected utilization of Idaho fescue in the savanna community (Table 6). Idaho fescue in grazed plots received $19.3 \%$ utilization while $0.4 \%$ utilization occurred in ungrazed plots. Utilization was heavier under Sequence $1(\bar{x}=16.4 \%)$ than under Sequence $2(\bar{x}=3.2 \%)$, and utilization was greater in $1994(\bar{x}=16.1 \%)$ than in 1993 $(\bar{x}=3.6 \%)$.

Treatment, period, and year effects influenced the number of reproductive culms per Idaho fescue plant (Table 6). Grazing $(\bar{x}=1.6)$ reduced reproductive culms per plant relative to grazing exclusion $(x=2.3)$. Number of reproductive culms per plant declined between June $(\bar{x}=2.4)$ and November $(\bar{x}=1.5)$, and more reproductive culms occured in 1993 $(\overline{\mathrm{x}}=2.9)$ than in $1994(\overline{\mathrm{x}}=1.1)$.

Significant treatment, period, and year effects were detected for CP of Idaho fescue (Table 6). Grazing increased CP of Idaho fescue $(\overline{\mathrm{x}}=5.8 \%)$ relative to grazing exclusion $(x=4.8 \%)$. Crude protein increased between November $(\overline{\mathrm{x}}=5.0 \%)$ and March $(\overline{\mathrm{x}}=5.6 \%)$, and CP was higher in $1994(\bar{x}=6.0 \%)$ than in $1993(\bar{x}=4.6 \%)$.

Period also affected in vitro dry matter digestibility of Idaho fescue (Table 6). In vitro dry matter digestibility declined between November $(\mathrm{x}=44.3 \%)$ and March $(\bar{x}=41.8 \%)$.

A year effect was detected for the standing crop of Idaho fescue (Table 6). The standing crop was greater in 1993 $\left(\bar{x}=136.2 \mathrm{~kg} \mathrm{ha}^{-1} \mathrm{DM}\right)$ than in 1994 $\left(\bar{x}=101.9 \mathrm{~kg} \mathrm{ha}^{-1} \mathrm{DM}\right)$.

\section{Elk Sedge-Savanna Community}

Utilization of elk sedge in the savanna community was affected by treatment, canopy, sequence, year, and the interaction of treatment by canopy (Tables 7 and 8 ). Crude protein of elk sedge was influenced by canopy and sequence effect (Table 7). Crude protein was higher under the tree canopy $(\bar{x}=5.3 \%)$ than in openings $(\bar{x}=4.8 \%)$. Crude protein was greater under Sequence $2(\bar{x}=5.2 \%)$ than under Sequence $1(\overline{\mathrm{x}}=4.9 \%)$.

Significant treatment, sequence, and year effects were detected for IVDMD of elk sedge (Table 7). Grazing produced an IVDMD response in elk sedge opposite of that in bluebunch wheatgrass. In vitro dry matter digestibility of elk sedge in ungrazed plots was higher $(\bar{x}=53.7 \%)$ than in grazed plots $(\bar{x}=51.4 \%)$. Elk sedge under Sequence $2(\bar{x}=53.6 \%)$ was more digestibility than under Sequence 1 $(x=51.5 \%)$, and IVDMD of elk sedge was greater in $1993(x=53.7 \%)$ than in 1994 $(\bar{x}=51.4 \%)$. The standing crop of elk sedge in the savanna community was not affected by any of the variables measured (Table 7).

\section{Elk Sedge- Forest Community}

Utilization of elk sedge in the forest community was affected by treatment, sequence, and year (Table 9). Elk sedge in grazed plots received $12.7 \%$ utilization while $1.3 \%$ utilization occurred ungrazed plots. Utilization was greater under Sequence $1 \quad(\bar{x}=13.3 \%)$ than under Sequence $2(\overline{\mathrm{x}}=0.8 \%)$, and utilization was higher in $1994(\bar{x}=11.9 \%)$ than in 1993 $(\bar{x}=2.2 \%)$.

Treatment and sequence effects were detected for CP of elk sedge (Table 9). Grazing increased $\mathrm{CP}(\overline{\mathrm{x}}=6.3 \%)$ relative to grazing exclusion $(\bar{x}=5.8 \%)$. Crude protein was greater under Sequence 2 $(\bar{x}=6.7 \%)$ than under Sequence 1 $(\bar{x}=5.5 \%)$

Period, sequence, and year affected IVDMD of elk sedge (Table 9). In vitro dry matter digestibility declined between the November $(\bar{x}=55.0 \%)$ and March $(\bar{x}=52.3 \%)$ sampling periods. In vitro dry matter digestibility was greater under Sequence $2(\bar{x}=55.6 \%)$ than under Sequence $1(\bar{x}=51.7 \%)$, and IVDMD was higher in $1993(\bar{x}=54.6 \%)$ than in 1994 $(\bar{x}=52.7 \%)$. A sequence by canopy interaction was detected for the standing crop of elk sedge in the forest community (Table 9 and 10).

\section{Discussion}

\section{Forage Utilization}

Sequence and year effects detected for utilization on all 3 forage species likely

Table 5. Main effects and interactions, with their respective p-values, for response variables of Idaho fescue occurring in bunchgrass grasslands on the McCarty Spring Big Game Winter Range Management Area in northeastern Oregon during 1993 and 1994.

\begin{tabular}{|c|c|c|c|c|c|c|}
\hline $\begin{array}{l}\text { Main Effects } \\
\text { and Interactions }\end{array}$ & $\begin{array}{c}\text { Degrees of } \\
\text { Freedom }\end{array}$ & $\begin{array}{c}\text { Forage } \\
\text { Utilization }\end{array}$ & $\begin{array}{c}\text { Number of } \\
\text { Reproductive } \\
\text { Culms per Plant }\end{array}$ & Crude Protein & $\begin{array}{c}\text { In Vitro } \\
\text { Dry Matter } \\
\text { Digestibility }\end{array}$ & $\begin{array}{l}\text { Standing } \\
\text { Crop }\end{array}$ \\
\hline & & \multicolumn{5}{|c|}{ 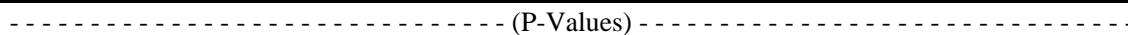 } \\
\hline $\mathrm{T}^{1}$ & 1 & $\mathbf{0 . 0 1 1 2}^{2}$ & 0.1261 & 0.0019 & 0.1101 & 0.4154 \\
\hline $\mathrm{P}$ & 1 & NA & 0.4011 & 0.1041 & 0.0068 & 0.7508 \\
\hline $\mathrm{T} * \mathrm{P}$ & 1 & NA & 0.9402 & 0.8891 & 0.1579 & 0.4462 \\
\hline $\mathrm{S}$ & 1 & 0.0245 & 0.1276 & 0.0280 & 0.2073 & 0.1587 \\
\hline $\mathrm{S} * \mathrm{P}$ & 1 & NA & 0.1596 & 0.0738 & 0.7648 & 0.8674 \\
\hline $\mathrm{Y}$ & 1 & 0.0248 & 0.0004 & 0.0001 & 0.2820 & 0.3255 \\
\hline
\end{tabular}

${ }_{\mathrm{T}}^{\mathrm{T}}=$ Treatment (grazed or ungrazed), $\mathrm{P}=$ Sampling period (June or November for reproductive culms and November or March for forage quality and quantity variables), $\mathrm{S}=$ Sequence or order of treatment application on a plot (ungrazed/grazed or grazed/ungrazed), and Y = Year (1993 or 1994).

${ }^{2} \mathrm{P}$-values $<0.05$ are printed in bold face. 
Table 6. Main effects and interactions, with their respective p-values, for response variables of Idaho fescue occurring in pine-bunchgrass savannas on the McCarty Spring Big Game Winter Range Management Area in northeastern Oregon during 1993 and 1994.

\begin{tabular}{|c|c|c|c|c|c|c|}
\hline $\begin{array}{l}\text { Main Effects } \\
\text { and Interactions }\end{array}$ & $\begin{array}{c}\text { Degrees of } \\
\text { Freedom }\end{array}$ & $\begin{array}{c}\text { Forage } \\
\text { Utilization }\end{array}$ & $\begin{array}{c}\text { Number of } \\
\text { Reproductive } \\
\text { Culms per Plant }\end{array}$ & Crude Protein & $\begin{array}{c}\text { In Vitro } \\
\text { Dry Matter } \\
\text { Digestibility }\end{array}$ & $\begin{array}{l}\text { Standing } \\
\text { Crop }\end{array}$ \\
\hline & & 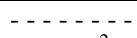 & - & - - (P-Values) - & - - - - - - - & $\ldots \ldots$ \\
\hline $\mathrm{T}^{1}$ & 1 & $0.0005^{2}$ & 0.0249 & 0.0005 & 0.6024 & 0.3460 \\
\hline $\mathrm{P}$ & 1 & NA & 0.0079 & 0.0218 & 0.0023 & 0.0871 \\
\hline $\mathrm{C}$ & 1 & 0.9641 & 0.8037 & 0.3318 & 0.3952 & 0.0904 \\
\hline $\mathrm{T} * \mathrm{P}$ & 1 & NA & 0.5253 & 0.7177 & 0.9034 & 0.6250 \\
\hline $\mathrm{T}^{*} \mathrm{C}$ & 1 & 0.9290 & 0.9863 & 0.2310 & 0.0981 & 0.6987 \\
\hline $\mathrm{P}^{*} \mathrm{C}$ & 1 & NA & 0.6064 & 0.3595 & 0.3099 & 0.4716 \\
\hline $\mathrm{T} * \mathrm{P} * \mathrm{C}$ & 1 & NA & 0.3960 & 0.6626 & 0.6993 & 0.7891 \\
\hline S & 1 & 0.0036 & 0.9791 & 0.1020 & 0.1262 & 0.9579 \\
\hline $\mathrm{S} * \mathrm{P}$ & 1 & NA & 0.1993 & 0.4220 & 0.1578 & 0.9757 \\
\hline $\mathrm{S} * \mathrm{C}$ & 1 & 0.6276 & 0.8219 & 0.3682 & 0.3108 & 0.1311 \\
\hline $\mathrm{S} * \mathrm{P} * \mathrm{C}$ & 1 & NA & 0.4692 & 0.2442 & 0.2094 & 0.1714 \\
\hline Y & 1 & 0.0048 & 0.0001 & 0.0001 & 0.0801 & 0.0364 \\
\hline
\end{tabular}

$\mathrm{T}=$ Treatment (grazed or ungrazed), $\mathrm{P}=$ Sampling period (June or November for reproductive culms and November or March for forage quality and quantity variables), $\mathrm{C}=\mathrm{Canopy}$ (present or absent), $\mathrm{S}=$ Sequence or order of treatment application on a plot (ungrazed/grazed or grazed/ungrazed), and $\mathrm{Y}=\mathrm{Year}(1993 \mathrm{or} 1994)$ ).

${ }^{2} \mathrm{P}$-values $<0.05$ are printed in bold face.

arose from differences in experience and foraging behavior between the 2 ewe-lamb bands. The band used in 1993, had no prior experience on the study area, remained agitated and alert, and tended to trail rather than forage through the grassland and savanna communities. They rarely ventured into the forest community. The sheep used in 1994 were well-experienced with the area and actively foraged in all 3 plant communities. These inherent differences between bands may have been compounded by higher reproductive culm production in 1993. An increase in reproductive culm density tends to reduce utilization of grasses by sheep (Murray 1984). The high density of reproductive culms present in 1993 likely reduced sheep utilization of bluebunch wheatgrass and Idaho fescue during that year. Both bands of sheep tended to forage in the openings and rest and ruminant under trees in the savanna community. This probably contributed to the canopy effects observed in utilization of elk sedge and treatment by canopy interactions that affected utilization of bluebunch wheatgrass (Tables 2 and 3 ) and elk sedge (Tables 7 and 8). It is unclear why the utilization of Idaho fescue was not affected by canopy or treatment by canopy interactions.

\section{Reproductive Culms}

Although late-spring grazing generally appeared to reduce numbers of reproductive culms in bluebunch wheatgrass and Idaho fescue, significant treatment effects were only observed for Idaho fescue in the savanna community (Table 6). Period effects on numbers of reproductive culms in bluebunch wheatgrass in grassland community (Table 1) and Idaho fescue in savanna community (Table 6) were likely a product of natural attrition caused by wind, early-season snowfall, and grazing by wild ungulates between June and November. Reproductive culm production is commonly used as an index of vigor for bluebunch wheatgrass. The occurrence of more reproductive culms in bluebunch wheatgrass in openings than under the tree canopy suggests bluebunch wheatgrass may endure more competition in open environments than under trees (Table 2).

Year was the most notable factor affecting numbers of reproductive culms in bluebunch wheatgrass (Tables 1 and 2) and Idaho fescue (Tables 5 and 6). Growing season precipitation was higher in 1993 than in 1994 (Fig. 1), this probably contributed to greater reproductive culm production in these species during 1993.

\section{Forage Quality and Quantity}

The levels of improvement in CP of bluebunch wheatgrass and Idaho fescue and IVDMD of bluebunch wheatgrass obtained with late-spring grazing could have substantial impact on the nutritional status of wintering elk (see Clark et al. 1998). The heavier utilization that occurred under Sequence 1 probably removed a larger proportion of apical meristems and foliage from bluebunch wheatgrass and Idaho fescue than did the

Table 7. Main effects and interactions, with their respective p-values, for response variables of elk sedge occurring in pine-bunchgrass savannas on the McCarty Spring Big Game Winter Range Management Area in northeastern Oregon during 1993 and 1994.

\begin{tabular}{|c|c|c|c|c|c|}
\hline $\begin{array}{l}\text { Main Effects } \\
\text { and Interactions }\end{array}$ & $\begin{array}{l}\text { Degrees of } \\
\text { Freedom }\end{array}$ & $\begin{array}{c}\text { Forage } \\
\text { Utilization }\end{array}$ & Crude Protein & $\begin{array}{c}\text { In Vitro } \\
\text { Dry Matter } \\
\text { Digestibility }\end{array}$ & Standing Crop \\
\hline $\mathrm{T}^{1}$ & $\begin{array}{c}----- \\
1\end{array}$ & $\begin{array}{l}----- \\
\mathbf{0 . 0 0 0 1}^{2}\end{array}$ & $\begin{array}{c}-(\%)--- \\
0.9036\end{array}$ & $\begin{array}{c}------ \\
0.0125\end{array}$ & $\begin{array}{c}------ \\
0.6499\end{array}$ \\
\hline $\mathrm{P}$ & 1 & NA & 0.7222 & 0.0613 & 0.0942 \\
\hline $\mathrm{C}$ & 1 & 0.0132 & 0.0018 & 0.1627 & 0.1587 \\
\hline $\mathrm{T}^{*} \mathrm{P}$ & 1 & NA & 0.6705 & 0.6751 & 0.1549 \\
\hline $\mathrm{T}^{*} \mathrm{C}$ & 1 & 0.0128 & 0.1620 & 0.6471 & 0.8118 \\
\hline $\mathrm{P} * \mathrm{C}$ & 1 & NA & 0.0608 & 0.1400 & 0.7267 \\
\hline $\mathrm{T} * \mathrm{P} * \mathrm{C}$ & 1 & NA & 0.2379 & 0.3264 & 0.9692 \\
\hline $\mathrm{S}$ & 1 & 0.0055 & 0.0246 & 0.0200 & 0.5320 \\
\hline $\mathrm{S} * \mathrm{P}$ & 1 & NA & 0.5878 & 0.5300 & 0.7231 \\
\hline $\mathrm{S} * \mathrm{C}$ & 1 & 0.1540 & 0.7700 & 0.6723 & 0.6933 \\
\hline $\mathrm{S} * \mathrm{P} * \mathrm{C}$ & 1 & NA & 0.4447 & 0.3467 & 0.6729 \\
\hline $\mathrm{Y}$ & 1 & 0.0115 & 0.1174 & 0.0133 & 0.3235 \\
\hline
\end{tabular}


Table 8. Mean levels of utilization (percent plant weight) on elk sedge as affected by treatment, sequence, year, and the interaction of treatment and canopy presence in pine-bunchgrass savannas on the McCarty Spring Big Game Winter Range Management Area in northeastern Oregon during 1993 and 1994.

\begin{tabular}{|c|c|c|c|c|c|c|c|}
\hline & \multirow[b]{3}{*}{ Treatment } & \multicolumn{2}{|c|}{ Sequence } & \multirow{2}{*}{\multicolumn{2}{|c|}{ Year }} & \multirow{2}{*}{\multicolumn{2}{|c|}{ Canopy }} \\
\hline & & \multirow{2}{*}{$\begin{array}{l}\text { Ungrazed- } \\
\text { Grazed }\end{array}$} & \multirow{2}{*}{$\begin{array}{c}\text { Grazed- } \\
\text { Ungrazed }\end{array}$} & & & & \\
\hline & & & & $\overline{1993}$ & 1994 & Absent & Present \\
\hline & ----- & ---- & ---- & -- & --- & --- & --- \\
\hline Ungrazed & $0.9 \mathrm{a}^{1}$ & 1.8 & 0.1 & 1.8 & 0.1 & $0.9 \mathrm{a}$ & $0.9 \mathrm{a}$ \\
\hline Grazed & $23.8 b$ & 35.0 & 12.7 & 12.7 & 35.0 & $33.9 b$ & $13.8 \mathrm{c}$ \\
\hline Mean & 12.4 & $18.4 \mathrm{a}$ & $6.4 \mathrm{~b}$ & $7.2 \mathrm{a}$ & $17.5 b$ & $17.4 \mathrm{a}$ & $7.4 \mathrm{~b}$ \\
\hline
\end{tabular}

${ }^{1}$ Means for main effects or treatment by canopy interactions which share a common letter are not significantly different $(\mathrm{P}>0.05)$.

lighter grazing that occurred under Sequence 2. This may explain the higher $\mathrm{CP}$ of Idaho fescue (Table 5) and IVDMD of bluebunch wheatgrass (Table 1) detected under Sequence 1. If the apical meristems are left intact following defoliation, grazed tillers continue to develop leaves and elongate. Consequently, light grazing of bluebunch wheatgrass and Idaho fescue may have had little effect on the phenological development or forage quality relative to grazing exclusion (Stoddart 1946). Removal of apical meristems and foliage by heavier grazing stimulates regrowth from axillary buds (Mueller and Richards 1986, Richards et al. 1998), effectively delaying plant development and potentially allowing plants to cure at a younger phenological stage.

Given a lack of information on the physiology of elk sedge, its forage quality responses are difficult to interpret. Additional research is needed to improve our understanding of elk sedge and its responses to grazing.

Bluebunch wheatgrass in the grassland community was the only case where utilization was heavy enough to cause significant declines in the standing crop (Table 1). Winter ranges in northeastern Oregon are forage quality- rather than quantitylimited. Even in March, when the standing crop of bluebunch wheatgrass in the grassland community of grazed plots was the lowest $\left(=87.6 \mathrm{~kg} \mathrm{ha}^{-1} \mathrm{DM}\right)$, bluebunch wheatgrass forage from only 17 ha of grassland would supply the daily dry matter needs of 300 adult cow elk, the typical winter population on the study area (i.e., assuming $5 \mathrm{~kg} \mathrm{DM}$ each or $2.5 \%$ of 200 kg body weight) (see Hobbs et al. 1982 and Clark et al. 1998). Consequently, it is unlikely the reduced standing crop observed in this study would limit forage availability for wintering elk.

Increases in CP of bluebunch wheatgrass (Table 2) and Idaho fescue (Table 6) between the November and March sampling periods were probably due to proportionately lower standing litter content and higher live tissue content in March samples. Forage quality of standing litter is typically lower than that of live tissue. Given the significant period effects detected for numbers of reproduction culms in bluebunch wheatgrass and Idaho fescue, it is likely total standing litter in these species continued to decline (particularly older, degraded litter of low forage quality) between November and March. This probably reduced the standing litter content and increased the forage quality of March samples. Additionally, under favorable winter and early spring conditions, bluebunch wheatgrass may resume growth of tillers initiated during the previous fall (Blaisdell and Pechanec 1949). This would increase the amount of live tissue in March relative to November samples. Both bluebunch wheatgrass (McIlvanie 1942, Evans and Tisdale 1972, Wilson et al. 1966) and Idaho fescue (Borman 1990) may initiate spring growth in early March. Given the assumptions above, one might expect both CP and IVDMD of bluebunch wheatgrass and Idaho fescue to increase between November and March.

Table 9. Main effects and interactions, with their respective p-values, for response variables of elk sedge occurring in mixed-conifer forests on the McCarty Spring Big Game Winter Range Management Area in northeastern Oregon during 1993 and 1994.

\begin{tabular}{|c|c|c|c|c|c|}
\hline $\begin{array}{l}\text { Main Effects } \\
\text { and Interactions }\end{array}$ & $\begin{array}{c}\text { Degrees of } \\
\text { Freedom }\end{array}$ & $\begin{array}{c}\text { Forage } \\
\text { Utilization }\end{array}$ & Crude Protein & $\begin{array}{c}\text { In Vitro } \\
\text { Dry Matter } \\
\text { Digestibility }\end{array}$ & $\begin{array}{l}\text { Standing } \\
\text { Crop }\end{array}$ \\
\hline $\mathrm{T}^{1}$ & $--\frac{-}{1}$ & $\overline{0.0006}{ }^{2}$ & $\begin{array}{c}-(\text { P-Values })- \\
\mathbf{0 . 0 4 9 5}\end{array}$ & ----- & ---- \\
\hline $\mathrm{P}$ & 1 & NA & 0.2513 & 0.0023 & 0.3995 \\
\hline $\mathrm{C}$ & 1 & 0.0598 & 0.1910 & 0.6826 & 0.7470 \\
\hline $\mathrm{T} * \mathrm{P}$ & 1 & NA & 0.5891 & 0.5772 & 0.7968 \\
\hline $\mathrm{T}^{*} \mathrm{C}$ & 1 & 0.0805 & 0.8481 & 0.9871 & 0.4169 \\
\hline $\mathrm{P}^{*} \mathrm{C}$ & 1 & NA & 0.8052 & 0.8545 & 0.4401 \\
\hline $\mathrm{T} * \mathrm{P} * \mathrm{C}$ & 1 & NA & 0.8028 & 0.8209 & 0.7583 \\
\hline S & 1 & 0.0004 & 0.0001 & 0.0001 & 0.1215 \\
\hline $\mathrm{S} * \mathrm{P}$ & 1 & NA & 0.2530 & 0.8806 & 0.1257 \\
\hline $\mathrm{S} * \mathrm{C}$ & 1 & 0.1053 & 0.4137 & 0.9932 & 0.0451 \\
\hline $\mathrm{S} * \mathrm{P} * \mathrm{C}$ & 1 & NA & 0.6000 & 0.8453 & 0.2765 \\
\hline $\mathrm{Y}$ & 1 & 0.0016 & 0.3731 & 0.0176 & 0.8591 \\
\hline
\end{tabular}

${ }^{\mathrm{T}} \mathrm{T}=$ Treatment (grazed or ungrazed), $\mathrm{P}=$ Sampling period (June or November for reproductive culms and Novembe or March for forage quality and quantity variables), $\mathrm{C}=$ Canopy (present or absent), $\mathrm{S}=$ Sequence or order of treatment application on a plot (ungrazed/grazed or grazed/ungrazed), and Y = Year (1993 or 1994).

${ }^{2} \mathrm{P}$-values $<0.05$ are printed in bold face. March but declined in the openings (Table 2 and 4). A possibility is that the openings of the savanna tended to remain snowcovered while areas under the canopy remained snow-free. Winter and early spring growth may have occurred under the canopy but not in the openings, and this resulted in more live tissue in samples from under the canopy. It is also unclear why IVDMD of Idaho fescue (Tables 5 and 6) actually decreased between November and March. Declines in IVDMD of elk sedge in the forest community between November and March were probably due to death and weathering of leaf tips and consumption of the higher quality portions of leaves by wintering elk (Table 9).

Canopy effects on $\mathrm{CP}$ of elk sedge may be related to differences in plant vigor (Table 7). Elk sedge in the openings appeared to be stressed, with short, light green leaves and dead tips, compared to elk sedge under the canopy which had long, dark green leaves. Elk sedge in the openings likely endured more intense solar radiation and competition from bunchgrasses than elk sedge under the canopy. Conversely, bluebunch wheatgrass in the openings of the savanna community exhibited more standing crop than under bunch wheatgrass is more competitive and vigorous in the openings than under the ree canopy (Table 2).

It is difficult to interpret the canopy by quence interaction affecting the standing crop of elk sedge in the forest community (Tables 9 and 10). Additional research is 
Table 10. Mean levels of standing crop for elk sedge as affected by the interaction of canopy presence and sequence or order of treatment application in mixed-conifer forests on the McCarty Spring Big Game Winter Range Management Area in northeastern Oregon during 1993 and 1994.

\begin{tabular}{lccc}
\hline \hline & & \multicolumn{2}{c}{ Sequence } \\
\cline { 2 - 3 } & Canopy & Ungrazed-Grazed & Grazed-Ungrazed \\
\hline & 124.9 & $119.8 \mathrm{a}^{1}$ & $129.9 \mathrm{a}$ \\
Absent & 131.1 & $167.3 \mathrm{~b}$ & $94.9 \mathrm{c}$ \\
Present & 128.0 & 143.5 & 112.4 \\
Mean & & $\left.11.2-1 \mathrm{kgh}^{-1} \mathrm{DM}\right)$ &
\end{tabular}

${ }^{1}$ Means for canopy by sequence interactions which share a common letter are not significantly different $(\mathrm{p}>0.05)$.

needed to improve our understanding of how elk sedge responds to defoliation and tree canopy presence.

Year effects on CP and IVDMD of bluebunch wheatgrass (Tables 1 and 2) and on $\mathrm{CP}$ of Idaho fescue (Tables 5 and 6) were probably due to a higher reproductive culm presence in 1993 and the occurrence of fall regrowth in 1994. Bryant (1993) reported CP and IVDMD of the reproductive culms and inflorescences of cured bluebunch wheatgrass forage were lower than leaf material. A similar relationship is likely for Idaho fescue. Higher fall precipitation in 1994 (Fig. 1) may have stimulated fall regrowth elevating the live tissue content in 1994 samples.

Year effects on IVDMD of elk sedge (Tables 7 and 9) were probably related to differences in spring precipitation between years (Fig. 1). Increased precipitation in 1993 may have enhanced elk sedge production. Samples collected in 1993 would then contain proportionately more current year growth which is probably more digestible than older material. If more production occurred in 1993, it apparently was not great enough to produce a year effect on the standing crop of elk sedge. Differences in growth season precipitation probably caused the year effects detected for the standing crop of bluebunch wheatgrass (Table 2) and Idaho fescue (Table 6) in the savanna community.

\section{Conclusions}

Experience of livestock can strongly influence their effectiveness as forage conditioning agents. Moderate levels of latespring sheep grazing can decrease numbers of reproductive culms in Idaho fescue. Numbers of reproductive culms present in bluebunch wheatgrass and Idaho fescue plants decline from June to November. Above-normal precipitation can increase reproductive culm production in bluebunch wheatgrass and Idaho fescue. Late-spring grazing can enhance winter
CP levels in bluebunch wheatgrass, Idaho fescue, and elk sedge and IVDMD of bluebunch wheatgrass. Forage quality of bluebunch wheatgrass and Idaho fescue is more responsive to moderate than light levels of late-spring grazing. Crude protein in bluebunch wheatgrass and Idaho fescue can increase between November and March while IVDMD of Idaho fescue and elk sedge may decrease. Winter levels of $\mathrm{CP}$ in elk sedge can improve under light spring grazing but grazing may cause declines in IVDMD of elk sedge. The winter standing crops of bluebunch wheatgrass, Idaho fescue, and elk sedge are not affected by light to moderate utilization during late spring.

Carefully-managed, late-spring grazing can be an effective means for improving the winter forage quality of bluebunch wheatgrass and Idaho fescue on big game winter range. Further research is needed to evaluate grazing as a tool for improving the winter forage quality of elk sedge. Although, the percentage point changes in CP and IVDMD obtained in this study appear small, these changes are actually quite substantial when compared to the low basal forage quality levels common to grassland winter range. These forage quality improvements can also be obtained at relatively low cost, applied to different portions of the winter range in subsequent years, and have a positive influence on the nutritional status of wintering elk. Latespring grazing could also improve the quality of livestock winter pasture and reduce supplementation costs for livestock producers. With some careful thought, a forage conditioning program could be integrated into existing rotation grazing systems.

\section{Literature Cited}

Anderson, E.W. and R.J. Scherzinger. 1975. Improving quality of winter forage for elk by cattle grazing. J. Range Manage. 28:120-125.
Association of Official Analytical Chemists (AOAC). 1980. Official methods of analysis. 13th ed. Assoc. of Official Anal. Chem., Washington, D.C.

Blaisdell, J.P. and J.F.Pechanec. 1949. Effect of herbage removal at various dates on vigor of bluebunch wheatgrass and arrowleaf balsamroot. Ecol. 30:298-305.

Borman, M.M. 1990. Growth patterns of perennial grasses in the annual grassland type of southwest Oregon. Agron. J. 82:1093-1098.

Bryant, L.D. 1993. Quality of bluebunch wheatgrass (Agropyron spicatum) as a winter range forage for Rocky Mountain elk (Cervus elaphus nelsoni) in the Blue Mountains of Oregon. Ph.D. Diss., Oregon State Univ., Corvallis, Ore.

Clark, P.E., W.C. Krueger, L.D. Bryant, and D.R. Thomas. 1998. Spring defoliation effects on bluebunch wheatgrass. I. Winter forage quality. J. Range Manage. 51:519-525.

Dysterhuis, E.L. and C.T. High. 1985. Soil survey of Union County area, Oregon. USDA Soil Conserv. Serv., Washington, D.C.

Evans, G.R. and E.W. Tisdale. 1972. Ecological characteristics of Aristida longise ta and Agropyron spicatum in west-central Idaho. Ecol. 53:137-142.

Franklin, J.F. and C.T. Dryness. 1973 Natural vegetation of Oregon and Washington. USDA Forest Serv., PNW Forest and Range Exp. Sta., Gen. Tech. Rep. PNW-8. Washington, D.C.

Frisina, M.R. and F.G. Morin. 1991. Grazing private and public land to improve the Fleecer Elk Winter Range. Rangelands. 13:291-294.

Ganskopp, D., R. Angell and J. Rose. 1992. Response of cattle to cured reproductive stems in a caespitose grass. J. Range Manage. 45:401-404.

Hall, F.C. 1973. Plant communities of the Blue Mountains in eastern Oregon and southeastern Washington. USDA Forest Serv., Area Guide R6 3-1. Washington, D.C.

Hobbs, N.T., D.L. Baker, J.E. Ellis, D.M. Swift, and R.A. Green. 1982. Energy- and nitrogen-based estimates of elk winter-range carrying capacity. J. Wildl. Manage. 46:12-21.

Jourdonnais, C.S. 1985. Prescribed fire and cattle grazing influences on the vegetation and elk use of a rough fescue community. M.S. Thesis, Univ. Montana, Missoula, Mont.

Jourdonnais, C.S. and D.J. Bedunah. 1990. Prescribed fire and cattle grazing on an elk winter range in Montana. Wildl. Soc. Bull. 18:232-240.

McIlvanie, S.K. 1942. Carbohydrate and nitrogen trends in bluebunch wheatgrass, Agropyron spicatum, with special reference to grazing influences. Plant Physiol. 17:540-547.

Mueller, R.J. and J.H. Richards. 1986. Morphological analysis of tillering in Agropyron spicatum and Agropyron deserto 
rum. Annals of Bot. 58:911-921.

Murray, R.B. 1984. Yields, nutrient quality, and palatability to sheep of fourteen grass accessions for potential use on sagebrushgrass range in southeastern Idaho. J. Range Manage. 37:343-348.

Pechanec J.F. and G.D. Pickford. 1973. A comparison of methods used in determining percentage utilization of range grasses. J. Agr. Res. 54:753-765.

Pitt, M.D. 1986. Assessment of spring defoliation to improve fall forage quality of bluebunch wheatgrass (Agropyron spicatum). J. Range Manage. 39:175-181.

Richards, J.H., R.J. Mueller, and J.J. Mott. 1988. Tillering in tussock grasses in relation to defoliation and apical bud removal. Annals of Bot. 62:173-179.
SAS. 1988. SAS/STAT user's guide. 6.03 ed. SAS Institute Inc. Cary, N.C.

Sheehy, D.P. 1987. Grazing relationships of elk, deer, and cattle on seasonal rangeland in northeastern Oregon. Ph.D. Diss., Oregon State Univ., Corvallis, Ore.

Skovlin, J.M. and M. Vavra. 1979. Winter diets of elk and deer in the Blue Mountains, Oregon. USDA For. Serv. Res. Paper PNW260. Washington, D.C.

Stoddart, L.A. 1946. Some physical and chemical responses of Agropyron spicatum to herbage removal at various seasons. Utah State Agr. Coll. Agr. Exp. Sta. Bull. 324. Logan, Ut.
Tilley, J.M.A. and R.A. Terry. 1963. A 2stage technique for the in vitro digestion of forage crops. J. Brit. Grassl. Soc. 18:104-111.

Westenskow-Wall, K.J., W.C. Krueger, L.D. Bryant, and D.R. Thomas. 1994. Nutrient quality of bluebunch wheatgrass regrowth on elk winter range in relation to defoliation. J. Range Manage. 47:240-244.

Wilson, A.M., G.A. Harris, and D.H. Gates. 1966. Cumulative effects of clipping on yield of bluebunch wheatgrass. J. Range Manage. 19:90-91. 